Asian Community Health

Nursing Research

\title{
Factors Associated with Fruit and Vegetables Consumption Behavior Among Adolescents Based on The Health Promotion Model
}

\author{
Arbianingsih Arbianingsih",a*, Mulyana Anwar2,b, Huriati Huriati1,c, and Nur Hidayah ${ }^{2, d}$ \\ 1Pediatric Nursing, Medical and Health Sciences Faculty, Universitas Islam Negeri Alauddin, Makassar, \\ Indonesia; \\ ${ }^{2}$ Nursing School, Medical and Health Sciences Faculty, Universitas Islam Negeri Alauddin, Makassar, Indonesia; \\ aarbianingsih.tiro@uin-alauddin.ac.id; bmulyanaanwar04@gmail.com; churiati.bahuddin@uin-alauddin.ac.id; \\ dnur.hidayah@uin-alauddin.ac.id;
}

Type of the Paper (Article)

Received: January 11, 2021; Accepted: April 5, 2021; Published: August 13, 2021

https://doi.org/10.29253/achnr.2021.3157

\begin{abstract}
Background-The low consumption of fruits and vegetables is one of the risk factors for death in the world. Indonesia is a country that is rich in fruits and vegetables but has a low consumption level. The lowest age group in consuming fruit and vegetables is adolescents. Purpose-The purpose of this study was to determine the factors that influence fruit and vegetable consumption behavior in adolescents based on the Health Promotion Model Nola J. Pender. Methodology-This study used a descriptive-analyticcross-sectional study design involving 249 adolescents. The data was collected using a questionnaire to measure the factors that influence fruit and vegetable consumption behavior and food frequency questionnaire. The questionnaires were distributed online via social media for two weeks. Data were analyzed using linear regression. Result-Factors that influence fruit and vegetable consumption behavior in adolescents are resistance to action $(p=0.05)$, self-efficacy $(p<0.001)$, parental interpersonal influence $(p<0.001)$, and peer influence $(p=0.05)$. Ethnic factors, knowledge of benefits, and the environment do not have a significant effect on fruit and vegetable consumption behavior among adolescents. There are still $93.4 \%$ other factors that also influence fruit and vegetable consumption behavior in adolescents.To promote healthy consumption behavior of fruit and vegetable in adolescents we should increase the self-efficacy of adolescents, involved parents and peer groups as a role model for healthy behavior.
\end{abstract}

Keywords: adolescents; behavior; fruit and vegetable; health promotion

\section{Introduction}

One of the factors causing the likelihood of the world's highest mortality rate, namely the low fruit and vegetable consumption activity (Windratie, 2015). It is estimated that about 6.7 million people worldwide are dying due to a lack of fruit and vegetable intake, according to WHO (2014). Lack of consumption of fruits and vegetables can cause coronary heart disease, stroke, and certain types of cancer around the world and can also cause obesity problems which will increase the risk of osteoporosis and type II diabetes. In general, recommend the consumption of fruits and vegetables for a healthy life of 400 grams per person per day, consisting of 150 grams of fruit and 250 grams of vegetables.(WHO, 2014). 
The low consumption behavior of fruits and vegetables can be seen in Europe, such as in Germany, the population that consumes less fruit and vegetables is around 54.8\%, in France about 64.3 people who consume less fruit and vegetables, while in Italy around 77\% consume less. fruit and vegetables (Eurostot, 2015). In Asia, Indonesia is a country that is rich in fruits and vegetables but has less fruit and vegetable consumption (Nurlidyawati, 2015). In South Sulawesi, 95.5\% of the population does not consume fruits and vegetables, meaning that only $4.5 \%$ of the population consumes fruits and vegetables (Riskesdas, 2018).

The lowest age group in consuming fruits and vegetables both in urban and rural areas is adolescents. According to the age group and the food survey in Indonesia in 2014, the consumption of vegetables and processed products aged 13-18 years was 45.8 grams per day, while the consumption of fruits and processed products aged 13-18 years was 25.2 grams (Balitbangkes, 2014; Hermina, 2016). Adolescents aged $>10$ years in Makassar City who consume fruits and vegetables as recommended are only $9 \%$, meaning that there are $91 \%$ who do not consume fruits and vegetables (Riskesdas, 2013). This shows the need for an effort to improve fruit and vegetable consumption behavior among adolescents in Makassar City.

To increase the behavior factor of fruit and vegetable consumption, a concept or model is needed which is expected to increase the behavior promotive. Nola J. Pender's Health Promotion Model (HPM) is a conceptual model of nursing that focuses on promoting healthy behavior. Therefore, this study tries to explore the factors that influence fruit and vegetable consumption behavior in adolescents so that it can be an input to increase efforts to increase fruit and vegetable consumption behavior in adolescents.

\section{Literature Review}

The health promotion model (HPM) is a way to describe human interactions with the physical and interpersonal environment in various dimensions (Pender, 2011). The health promotion model was first developed by Nola J Pender in 1987. This HPM was built from research on 7 cognitive perception factors and 5 behavior modification factors that influence and predict health behavior (Genakama, 2019). This Health Promotion theory develops into two theories, namely the theory of expectation values (Expectancy-Value) and social learning theory (Social Cognitive Theory) in the human nursing perspective is seen as a holistic function (Nursalam, 2017). The elements in the Health Promotion Model can be seen in the Figure 1.

\section{Methodology}

This research was conducted using descriptive-analytic with a cross-sectional design, to analyze the contribution of age, ethnicity, motivation, attitude to the benefits of action, perceived barriers, selfefficacy, peers, parents, and the environment as independent variables and fruit and vegetable consumption behavior as an independent variable. dependent variable. This research was conducted on a group of early adolescents of Junior High School (SMP) students in Makassar City in July 2020.

The data was collected using a questionnaire to measure the factors that influence fruit and vegetable consumption behavior with a Cronbach alpha value of 0.813 . The measurement scale is in the form of a Likert with 25 items of questions. The measurement of fruit and vegetable consumption behavior used a food frequency questionnaire (FFQ). The questionnaire was distributed online via social media for two weeks. The number of representative samples is calculated using the Lameshow formula and adding $10 \%$ to anticipate drop out. A total of 249 adolescents who met the criteria and filled out the questionnaire completely were involved in this study. Sampling was carried out by snowball sampling.

The data analysis technique in this study used Linear Regression with a significance level of 0.05. This research has passed an ethical clearance from the Faculty of Medicine and Health Sciences UIN Alauddin Makassar with No.C.019 / KEPK / FKIK / IV / 2020. 


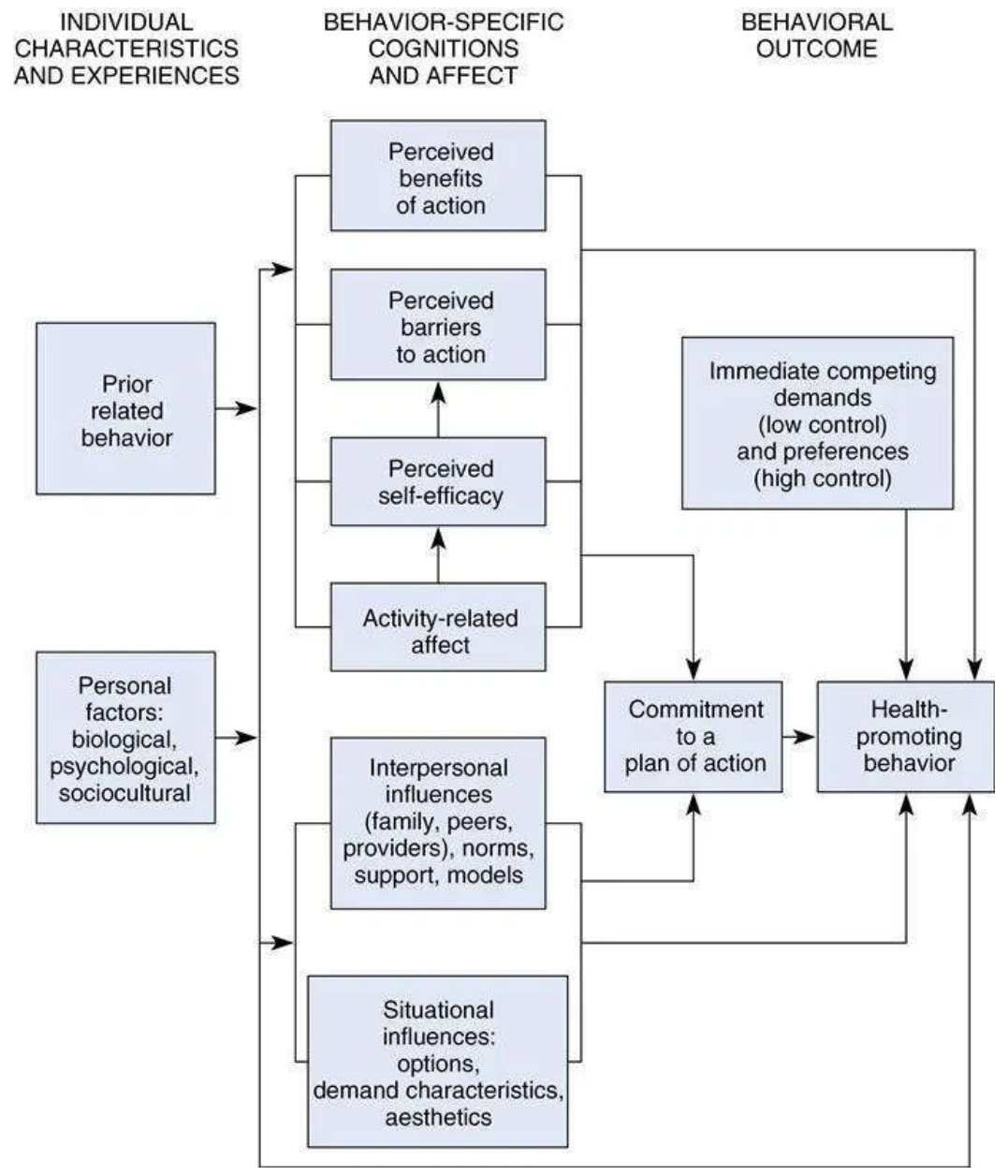

Figure 1. Health Promotion Model Elements.

\section{Result}

\section{Respondents Characteristics}

The majority of respondents in the study were 13 years of age, all of whom came from ethnic groups in the South Sulawesi Regency, and were dominated by female respondents (Table 1).

Table 1. Respondents Characteristics.

\begin{tabular}{lcc}
\hline Characteristics & Frequency (f) & Percentage (\%) \\
\hline Age: & 109 & \\
13 yo & 83 & $43.8 \%$ \\
14 yo & 57 & $33.3 \%$ \\
15 yo & & $22.9 \%$ \\
Ethnic: & 158 & $63.5 \%$ \\
Makassar & 78 & $31.3 \%$ \\
Bugis & 7 & $2.8 \%$ \\
Toraja & 6 & $2.4 \%$ \\
Mandar & & \\
Sex: & 171 & $68.7 \%$ \\
Female & 78 & $31.3 \%$ \\
Male & & \\
\hline
\end{tabular}


Analysis of the influence of factors that influence fruit and vegetable consumption behavior in adolescents based on the theory of the Health Promotion Model

The results of this study indicate that there is a significant correlation between perceived inhibition factors, self-efficacy, the influence of parents and peers $(\mathrm{p}<0.05)$. Ethnicity, motivation, attitude, and environmental benefits did not have a significant correlation with fruit and vegetable consumption behavior among adolescents. For more details, it is described in the following Figure:

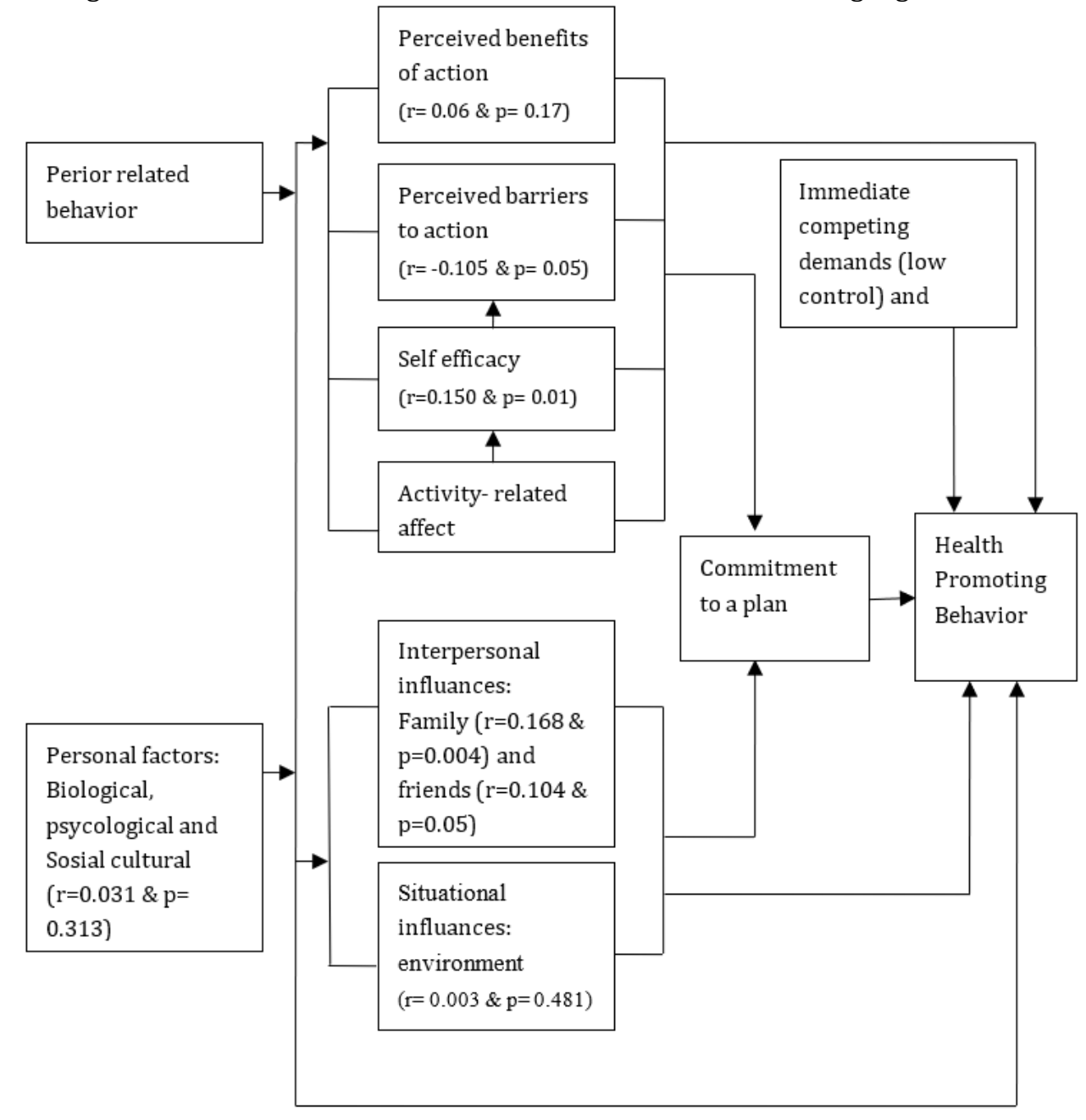

Figure 1. Factors associated with fruit and vegetables consumption behavior based on Health Promotion Model.

Of all the factors studied simultaneously gave an influence of $5.4 \%$ on fruit and vegetable consumption behavior in adolescents. This shows that there are still many other factors that influence consumerbehavior that has not been included in this study. However, based on the Nola J. Pender's health promotion theory model, it was found that the factors that are important to get attention to changing behavior are perceived barriers, self-efficacy, the influence of parents and peers.

\section{Discussion}

\section{The effect of ethnic on adolescent fruit and vegetable consumption}

Based on the results of the partial test, the effect of tribal factors did not significantly influence the behavior of fruit and vegetable consumption among adolescents with a p-value of $0.393(p>0.05)$. This is because all respondents come from allied tribes in South Sulawesi, where the 4 tribes have similar or the same characteristics and behavioral culture. The results of the same study say that a person's culture or ethnicity, in this case, the belief in things that are considered taboo, such as fruit and vegetable 
consumption, is not influenced by the behavior of consuming fruit and vegetables in adolescents (Nagawa, 2018). In line with Purwonugroho's research (2018), based on the results of interviews with informants, almost all informants said they believed in the benefits of fruit and vegetables and there was no belief or belief related to their culture not to eat vegetables. It is known that the Office of Minority Health $(\mathrm{OMH})$ describes culture as the ideas, communications, actions, habits, beliefs, values , and customs of racial, ethnic, religious, or social groups (Perry and Potter, 2009).

\section{The effect of motivation on adolescent fruit and vegetable consumption}

Based on the results of the partial test, the influence of the motivation factor did not significantly influence the behavior of fruit and vegetable consumption among adolescents with a p-value of 0.313 (p> 0.05). This is evidenced by the value of the strength of the relationship, namely 0.03 , which means that the strength of the relationship between motivation and consumer behavior is not significantly or weakly correlated. This is because there is no strong motivation from within adolescents or from other people and if the individual does not have the motivation to eat fruit and vegetables, the teenager will not try to consume fruits and vegetables, on the contrary, if someone has strong motivation in himself or herself. from other people in consuming fruits and vegetables, someone or teenagers will try to realize the action to eat fruits and vegetables (El-Fiky, 2011).

\section{The effect of perceived benefit of action on adolescent fruit and vegetable consumption}

Based on the results of the partial test, the effect of the perceived benefits of action did not significantly influence the fruit and vegetable consumption behavior of adolescents with a p-value of 0.17 ( $p>0.05)$. This is evidenced by the value of the strength of the relationship, namely 0.06 , which means that the strength of the relationship between attitudes towards consumption behavior is not significantly correlated. This is because the attitude of adolescents is not good enough to choose a type of food, so the behavior of adolescents in consuming fruits and vegetables will get worse. This is in line with research conducted by Hassan (2013) which states that there is no significant relationship between attitudes towards fruit and vegetable consumption. Then another study which states that the attitudes and behavior of fruit and vegetable consumption are not significant (Kurniawan, 2019).

\section{The effect of perceived barriers to action on adolescent fruit and vegetable consumption}

By conducting a partial test, the effect of the inhibition factor has a significant effect on the behavior of fruit and vegetable consumption among adolescents with a p-value of $0.005(p<0.05)$. This is evidenced by the value of the strength of the relationship, which is -.015 , which means that the strength of the relationship is negative. It can be concluded that the perceived barriers are negatively related to fruit and vegetable consumption, with the perceived barrier factor getting bigger and the fruit and vegetable consumption behavior of adolescents is getting less.

The obstacles that usually occur in consuming fruit and vegetables are due to a large number of fast food, unavailability of fruits and vegetables, one's preference for certain foods, and pocket money in buying food (Rachman et al., 2017). According to research by Lestari (2013), the presence of fast food as a food industry in Indonesia, especially in cities, can affect diet. This is in line with research (Al-saad, 2016) which states that modern life has made fast food a major part of daily life and it is known that fast food has a negative impact on health. In the study (Rachman et al., 2017) said that the food availability of SMPK 1 Harapan students had a significant relationship with fruit and vegetable consumption behavior.Furthermore, the provision of food is usually influenced by the consumption patterns of adolescents for the food they will consume if more food availability means more opportunities. in consuming larger food, on the other hand, if the availability of food is lower, the person's ability to eat food is increasingly difficult. This is in line with the research of Kurniawan (2019) which states that there is a significant relationship between the availability of fruit and vegetables and fruit and vegetable consumption behavior. However, it is different from Nurlidyawati's (2015) research that there is no significant relationship related to the availability of fruits and vegetables at home with consumption behavior.

\section{The effect of self-efficacy on adolescent fruit and vegetable consumption}

In the results of the partial test, the effect of the self-efficacy factor has a significant effect on fruit and vegetable consumption behavior in adolescents with a p-value of $0.009(p<0.05)$. This is evidenced 
by the strength of the relationship, namely 0.15 , which means that the strength of the relationship between self-efficacy and consumption behavior is weakly correlated. It is said that self-efficacy is a belief in one's ability, where if the adolescent's belief in the benefits of consuming good fruits and vegetables will improve adolescent behavior. It is proven in Anggraeni's (2018) research that there is a significant difference between respondents who have good self-efficacy and respondents who have less conscientious self-efficacy. This also says that self-efficacy is the first step in planning and one's behavior, in other words, the behavior of consuming fruits and vegetables, therefore every person or teenager who has good self-efficacy will try a good or difficult behavior. This study is in line with Granner and Evans (2012) and Pearson, Ball \& Crawford, (2012) which states that self-efficacy has a significant relationship with fruit and vegetable behavior. Other studies also say there is a significant relationship between the stages of change in consuming more fruits and vegetables such as balance decisions and self-efficacy. Another study suggests that there is a relationship between self-confidence and consumption of fruits and vegetables (Fibrihirsani, 2012).

\section{The effect of parents influences on adolescent fruit and vegetable consumption}

The results of the partial test of the effect of parental factors significantly influence the behavior of fruit and vegetable consumption among adolescents with $p$-value $0.04(p<0.05)$. This is evidenced by the strength of the relationship, which is 0.16 , which means that the strength of the relationship between parents and consumption behavior is weakly correlated. Evidenced by the results of a research according to Muna (2019) the attachment of parents who are said to be family is a factor related to fruit and vegetable consumption behavior in adolescents because the better the influence of parents with adolescents, the greater the chances of the availability of fruit and vegetables at home compared to respondents poor parental influence. According to (Pearson, et al., 2009) said that everyone can consume fruit and vegetables more than usual if their family or parents like or often eat fruits and vegetables well (Nurlidyawati, 2015). In line with Purba's research (2019), it is said that the attachment of parents to the availability of fruits and vegetables is related to children's behavior. Research according to Fibrihirsani (2012) shows that there is a significant relationship between parental support and consumption of fruits and vegetables. So it can be said that parents who have good influence always provide fruit and vegetables at home (Anggraeni, 2018).

\section{The effect of peers influences on adolescent fruit and vegetable consumption}

Based on the results of the partial test, the effect of peer factors has a significant effect on fruit and vegetable consumption behavior in adolescents with a p-value of $0.05(\mathrm{p}<0.05)$. This is evidenced by the strength of the relationship, namely 0.10 , which means that the strength of the relationship between peers on consumption behavior is correlated but the correlation is weak. The results of research conducted by Sholehah et al. (2016) said that there was a significant relationship between peers and the consumption of fruits and vegetables. Adolescents who are influenced by negative friends are at four times lower risk of consuming fruits and vegetables than adolescents who are influenced by positive friends. Likewise in research (Muna \& Mardiana, 2019) which said there was a significant relationship between peers and the consumption of fruits and vegetables for adolescents. This is also in line with the research of Fibrihirsani (2012) which states that there is a significant relationship between peers and consumption of fruits and vegetables.

\section{The effect of situational influences on adolescent fruit and vegetable consumption}

The results of the partial test showed that the influence of environmental factors did not significantly influence the behavior of fruit and vegetable consumption among adolescents with a $p$-value of 0.481 ( $p>0.05$ ). This is evidenced by the value of the strength of the relationship, namely 0.003 , which means that the strength of the relationship between the environment and consumer behavior is not significantly correlated. The reason is that the youth environment does not see or hear information about the importance of the benefits of consuming fruits and vegetables. This is in line with Lestari's research (2013) which also states that there is no significant relationship between external factors, especially advertising media, on the behavior in consuming fruits and vegetables. However, there was a tendency for respondents to consume enough fruit and vegetables if they often read or hear information from their environment compared to people who have never read or heard information about the importance of fruits and vegetables for health. Another study said there was no relationship between media exposure 
and fruit and vegetable consumption behavior in rural-urban Yogyakarta (Oktavia et al., 2019). Often someone is exposed to information related to health can make someone's knowledge more open to choosing good and healthy foods, especially fruits and vegetables (Rahmah et al., 2017).

\section{Conclusion}

Based onthe health promotion model (HPM) Nola J. Pender, factors that influence fruit and vegetable consumption behavior in adolescents are resistance to action, self-efficacy, parental interpersonal influence, and peer influence. Ethnic factors, knowledge of benefits, and the environment do not have a significant effect on fruit and vegetable consumption behavior among adolescents. There are still $93.4 \%$ other factors that also influence fruit and vegetable consumption behavior in adolescents. Therefore, further research may involve more variables that influence adolescent consumption behavior.

\section{Acknowledgement}

The authors would like to thanks the participants who took part in this study and also for the Nursing department of Medical and Health Sciences Faculty, Universitas Islam Negeri (UIN) Alauddin Makassar to support these research activities.

\section{References}

Al-saad, E. (2016). Causes And Effects Of Fast Food, 5(4), 279-280.

Anggraeni \& Sudiarti, N. A. \& T. (2018). Faktor Dominan Konsumsi Buah dan Sayur pada Remaja di SMPN 98 Jakarta, 5 No. 1, 18-32. https://doi.org/http://dx.doi.org/10.21776/ub.ijhn.2018.005.01.3

Balitbangkes. (2014). Buku Studi diet Total Survei Konsumsi Makanan Individu Indonesia 2014. Indonesia: Badan Penelitian dan Pengembangan Kesehatan Kementrian Kesehatan Republik Indonesi.

El-Fiky, I. (2011). 10 Keys To Ultimate Sucsses. Jakarta: Tugu Publisher.

Eurostot. (2015). Health Determinants: Consumption of Fruit and Vegetables.

Fibrihirsani, H. (2012). Hubungan antara Karakteristik Individu, Orang tua dan Lingkungan dengan Konsumsi Buah dan Sayur Siswa SDN Beji 5 dan 7 Depok Tahun2012.

Genakama, A. T. (2019). Analisis Faktor yang Berhubungan Dengan Perilaku Pencegahan Penularan TB Paru dengan Pendekatan Health Promotion Model. Surabaya: Skripsi.

Granner, M.L \& Evans, A.E., (2012). Measurement Properties of Psychosocial and Environmental Measures Associated with Fruit and Vegetable Intake among Middle School Adolescents. J Nutr Educ Behav. 44(1): 211

Hassan, C. D. S. dan A. (2013). Gambaran tentang Pengetahuan,sikap, dan Prakitik dalam Konsumsi Buah dan Sayur pada Siswa Kelas 4 SDN 04 Ciangsana Kabupaten Bogor Tahun 2012, 3, 1-17.

Hermina, P. S. dan. (2016). Gambaran Konsumsi Sayur dan Buah Penduduk Indonesia dalam Konteks Gizi Seimbang: Analisis Lanjut Survei Konsumsi Makanan Individu (SKMI) 2014. Buletin Penelitian Kesehatan, Vol. 44, N, 205-218.

Kurniawan, F. (2019). Perilaku Konsumsi Buah dan Sayur Pada Anggota Rumah Tangga. Stikes-Sitihajar, 1 Nomor 2 , $52-60$.

Lestari, A. D. (2013). Faktor-faktor yang Berhubungan dengan Perilaku Konsumsi Buah dan Sayur pada Siswa SMP Negeri 226 Jakarta Selatan. Skripsi, 1-89.

Muna \& Mardiana, N. I. (2019). Faktor-faktor yang berhubungan dengan Komsumsi Buah dan Sayur pada Remaja. Sport and Nutrition Journal, Vol 1 No 1, 1-11. Retrieved from https://journal.unnes.ac.id/sju/index.php/spnj/\%0A

Nagawa, M. et all. (2018). No TitlSocio-Ecological model factors influencing fruit and vegetable consumption among adolescents in Nakawa division, Kampala Capital City Authority, Ugandae. Preventive Medicine and Community Health, 1(3), 1-7.

Nurlidyawati. (2015). Faktor-faktor yang Berhubungan dengan Perilaku Komsumsi Buah dan Sayur pada Siswa Kelas VIII dan IX SMP Negeri 127 Jakarta Barat Tahun2015. Skripsi.

Nursalam. (2017). Metodologi Penelitian Ilmu Keperawatan. Edisi 4 (By S). Jakarta: Medika.

Oktavia dkk, A. R. dkk. (2019). Faktor - Faktor yang Berhubungan dengan Konsumsi Buah-Sayur pada. Keperawatan Raflesia, 1 Nomor 1, 33-44. https://doi.org/10.33088/jkr.vlil.400

Pender. (2011). The Health Promotion Model Manual. Retrieved from http://nursing.umich.edu/faculty-staff/nolaj-pender

Pearson, N., Atkin, A., Biddle, S., Gorely, T. \& Edwardson, C. (2009). Parenting styles, family structure and adolescent dietary behaviour. Public health nutrition, 13(8). 1245-53. 10.1017/S1368980009992217. 
Pearson, N., Ball, K., \& Crawford, D. (2012). Parental influences on adolescent fruit consumption: The role of adolescent self-efficacy. Health Education Research, 27(1), 14-23.

Perry and Potter. (2009). Fundamental Keperawatan (7th ed.). Jakarta: Salemba Medika.

Pearson, N., Atkin, A. J., Biddle, S. J., Gorely, T., \& Edwardson, C. (2009). Patterns of adolescent physical activity and dietary behaviours. International Journal of Behavioral Nutrition and Physical Activity, 6(1), 45.

Purba, C. vita G. E. all. (2019). Determinan Perilaku Konsumsi Buah dan Sayur pada Siswa SD Negeri 130 Kota Pekan Baru. Dunia Gizi, 2(1), 36-42.

Purwonugroho, S. (2018). Korelasi Penanganan Pangan Dengan Riwayat Kesehatan di Kecamatan Kopo Serang Banten.

Rachman dkk, B. N. (2017). Faktor yang berhubungan dengan perilaku konsumsi buah dan sayur siswa SMP di Denpasar. The Indonesian Jurnal of Nutrition, 6 no 1, 9-16.

Rahmah dkk, A. D. (2017). Perilaku konsumsi serat pada mahasiswa angkatan 2013 fakultas kesehatan masyarakat universitas halu oleo tahun 2017. JIMKESMAS, 2(6), 1-10.

Riskesdas. (2013). Laporan Hasil Riset Kesehatan Dasar Indonesia (Riskesdas) tahun 2013. Departemen Kesehatan Republik Indonesia.

Riskesdas. (2018). Hasil Utama Riskesdas, 88.

Sholehah, A., Andrias, D. R. \& Nadhiroh, S. R. (2016). Preferensi (kesukaan), pengetahuan gizi dan pengaruh teman sebaya dengan konsumsi buah dan sayur pada remaja. Adi Husada Nursing Journal, 2(2):1-6

WHO. (2014). Increasing fruit and vegetable consumption to reduce the risk of noncommunicable diseases. E-Library of Evidence for Nutrition Actions (eLENA).

Windratie. (2015). Pola Makanan Buruk Penyebab Kematian Dini Terbesar di Dunia. CNN Indonesia. 